\title{
直流配電を考慮した需要家サイドにおける
}

\section{FRIENDS 導入効果に関する検討}

\begin{tabular}{|c|c|c|c|}
\hline 学生貝 & 九里 & 晃一 & (北海道大学 \\
\hline 正 貝 & 北 & 裕幸 & （北海道大 \\
\hline 員 & 田中 & 英一 & 北海道大 \\
\hline & 長谷川 & 淳 & 海渞 \\
\hline
\end{tabular}

Analysis on Effects of FRIENDS in Demand Side Considering DC Distribution System

Koichi Kuri, Student Member, Hiroyuki Kita, Member

Eiichi Tanaka, Member and Jun Hasegawa, Member (Hokkaido University)

\begin{abstract}
The authors have already developed the Flexible, Reliable and Intelligent Electrical eNergy Delivery System (FRIENDS) as a future promissing delivery system. The most important function in FRIENDS is to execute customized power quality services by introducing Quality Control Center (QCC) between a distribution substation and electric consumers. Further, QCC can also supply a DC power directly using DC type dispersed generators such as fuel cell system (FC system), micro gas turbine (MGT). Therefore, if there are enough demands to the DC supply, introducing QCC or FC system (MGT) may give an economical value.

This paper considers a model of a quality control center which will be installed in an underground of an office building and analyzes the values of the DC supply using the model. Further, this paper proposes a method for determining the optimal capacity of facilities to be installed in QCC corresponding to the rate of DC demand to $\mathrm{AC}$ demand from an economical viewpoint. Also, this paper examines the optimal capacity of facilities to be installed in QCC considering the multi-quality power supply that classifies loads in the demand side according to the qualities.
\end{abstract}

キーワード：FRIENDS, 直流配電, 燃料電池, 交直変換器, 品質別供給, マイクロガスタービン

\section{1.まえがき}

近年，直流によって作動する機器が増加してきている。 例えば, インバータエアコンなどの空調機器や, 電子レン ジ, 電磁調理器, さらにはパソコンを中心とした情報機器 などがその代表的なものとして挙げられる。これらの機器 は，現状では個々に整流回路を持ち，商用電源から直流を 得ているが，その際に高調波や変換ロスが発生し，需要の 増加に伴い今後大きな問題となることが予想される。この 問題を解決するための一つの方策として, 直流電源を一般 家庭，集合住宅やオフィスビルなどの個々の需要家に導入 し，屋内電力を直流配電によって供給する方法”が考えら れる。このとき，新エネルギー電源として注目されている 然料電池 (Fuel Cell：FC)，太陽光発電や二次電池などの直 流型の小規模分散電源を用いることとすれば'|，効率的な 供給が可能となるだけでなくこうした新しい分散電源の
普及促進にも大きく奇与するものと考えられる。 ところで筆者らは，将来の配電システムの一形態として 「高柔軟・高信頼電気エネルギ一流通システム(Flexible, Reliable and Intelligent Electrical eNergy Delivery System: FRIENDS )」という新しい電力供給システムの概念を提案 しツ，その基礎的な梭討を行ってきている。FRIENDSで は, 配電用変電所と需要家との間に電力改質七ンター (Quality Control Center: QCC)という, 主に電力品質を改 善するための設備を新たに導入することを特徵としている 1。QCC 内部には，上記の上うな分散電源が備えられ， 需要家の多様なニーズに応じて様々な品質の電力を作り出 すことができ，「直流」についても供給すべき一つの電力 品質と考えている。そこで, QCC 加ら直接, 直流を供給 するという直流配電が, 直流負荷を持つ需要家において一 般的となれば，直流形の分散電源に対して必ずしも交直変 換器を設ける必要がないという経済的なメリットが生じ， $\mathrm{QCC}$ 全体のコストを抑えることができると期待される。 
本論文では，オフィスビルの地下などに設置されるであ ろう QCC を想定し，QCC が従来の交流供給に加え直流供 䊅をも行う場合の効果・価値について評価を行うことを目 的としている。直流配電の導入効果については, 文献[5][6] などで報告があるが，それらは直流供給システムを利用す ることにより従来の交流供給システムと比較して年間工ネ ルギーロスを隇少させるといった口ス面での評值や，完全 に直流供給システムと交流供給システムとに分けた場合の コスト比較による評価である。それに対して本論文では， 需要家の持つ総負荷に対する直流負荷の比率をバラメータ にとり，交直ハイブリッド型の供紿システムをモデルにす ることで現交流配電システムとのコスト比較を行い,さら には、QCC 内の分散電源容量, 变換器容量を決定する手 法を提案するという特徽を持っている。

\section{2. 直流型分散電源を考慮した直流配電導入奻果 の解析}

〈2・1〉想定する交直ハイブリッド型配電モデル 本章 では交直ハイブリッド型の配電システムをモデル化するた め，大きなエネルギ一消費があり，多くの電気機器を有す るオフィスビルを想定する。このオフィスビルの持つ交流 負荷, 直流負荷に対して, 系繶加5の交流電力と QCC 内 の然料電池（Fuel Cell； FC）からの直流電力とで供給する ことを考える。具体的には，图1に示すモデルを用いて検 討を行j|\{1|1\}。なお，図中のパラメータXは，棇負荷に対 する直流負荷の比率を示すものであるが，上り正確には， そのビルが QCC から受電する際の直流電力の比率を意味 している。すなわち、ここで言う「直流負荷」とは,ビル 内部の「直流で動作する負荷」そのものではなく、ビルが 「QCC 加受電する直流電力」のことを指している。例 えば，現在はビル内部にOA機器をはじめとして多くの直 流で動作する機器が存在するが, 系統からの受電はすべて 交流で行っている。この場合, 本論文では $\mathrm{X}=0.0$ と与元 ることとする。すなわち，X=0.0 とは，現状の交流受電方 式を意味することになる(第 3 章以降においても同様)。

このように, 本論文は, ビル内部の直流で動作する機器 と交流で動作する機器の実際の割合を考慮せずに,「どの 程度の割合で受電すると QCC にとって都合がよいか」と いう観点で評価するものである。従って，ここでは各々の

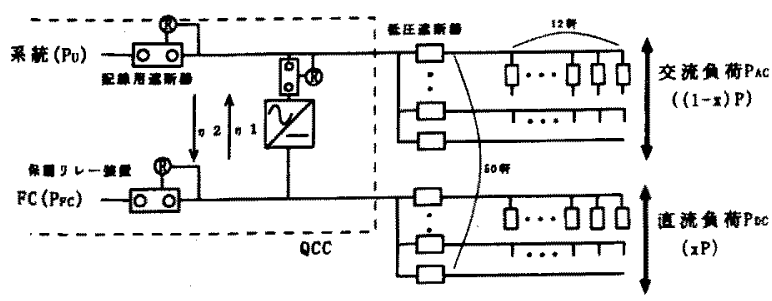

$\mathrm{x}$ : 直流負荷の比率, $\mathrm{P}:$ 棇負荷, $\eta 1, \eta 2:$ 変換器效率 图1ハイブリッド型交直配電システム

Fig. 1. AC-DC Hybrid Distribution System.
機器の使用電圧についても考虑していない。

\section{$\langle 2 \cdot 2\rangle$ 直流配電の導入効果に関する検討}

（1）評価手法需要家の総負荷に対する直流負荷の比 率 $(\mathrm{X})$ をパラメータとして与えたうえで，一日ごとにコス 卜を算出し，そ机らを皘算することにより，年間を通して の現交流配電システムとのコスト比較を行う。なお，総コ スト Fは，与えられた Xに対して，FC，コンバー夕等の 機器の連用量, 設備量を求め, 次式を用いて計算する。

$F=f\left(P_{l}\right)+f\left(P_{u}\right)+f_{\text {ti }}($ system $)$

$こ こ に, f\left(\mathbf{P}_{1}\right)$ : 買電コスト (電気料金 $\times$ 電力量),

$\mathrm{f}\left(\mathrm{P}_{\mathrm{w}}\right)$ : 燃料コス卜 (単価 $\times$ 出力), $\mathrm{f}_{\text {iin }}$ (system)

: システム全体の固定費，P：系統からの電力,

Pr：FC の出力, system：FC、コンバー夕, 配

電線, 保護装置等システム中の機器

ここで,FCの運転パターンとしては，以下の3通りを考 攄し娭討を行った。

(a)FCのDC 負荷への追徉運転

(b) FC 定格一定出力運転

(c) コスト最小化

(a)は，変換器による電力口スをできる限り削減すること を目的として，直流負荷には FC からその上下限制約に抵 触しない範囲で供給し，交流負荷には系統のみから供給す る運用パターンである。(b)は，他の要因（例えば、コジ エネとして用いる場合には十分大きな熱需要を满たすへく 一定出力で運転したり，あるいは寿命などを考慮して定格 出力で運転する場合など）により，FCの出力が決まって おり，その条件下でコストを最小化するよう運用するもの である。(c)は，系統， FCの何机的供給するにしても， とにかく総コストを最小にするよう運用するものである。

な技，FCの運転パターンが与えら扎㣗ば，直流負荷の 比率に店じて, コンバー夕容量, FC 出力, 各保讙装置の 容量などが一意的に決まるため，(1)式の固定費は，それ らの值を用いて容易に算定することができる。

（2）使用データ本猃文では，图2に示すような各期 間 (夏期, 冬期, 中間期) の負荷"有するオフィスビル を，一つの QCC の供給規模として想定した。ビルの地下 に設置されるであろう QCC の持つ配電設備として，容量 $1,300[\mathrm{~kW}]$ ，燃料単価 16.19 [ $¥ / \mathrm{kWh}]$ ，固定費 100,000 [ $/ \mathrm{kW}$ ]，年経費率 0.26 [耐用年数 5 年]の FC(下限值 $100 \mathrm{~kW})$ と, 入出力効率 $92 \%(\mathrm{DC} \rightarrow \mathrm{AC}), 93 \%(\mathrm{AC} \rightarrow \mathrm{DC})$, 固定費 $150,000[¥ / \mathrm{kVA}$ ]，年経費率 0.13 [酎用年数 15 年]の 双方向コンバータを保有しているものとする|市。また，配 電線の固定費は $\mathrm{AC}$ 線 3,000[¥/m], DC 線 4,000[¥/m]とし, 年経費率はともに0.10[耐用年数 25 年]とする。保護装置 の固定費は文献 [6]を参考にして表いに示すように与えた。

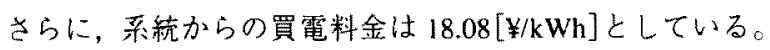
ここで，上記の年経費率は，金利 $6 \%$ とした定積償却分率 に，人件費，修繒費等の分を $2.5 \%$ とした值を加えて算定 したものである。 


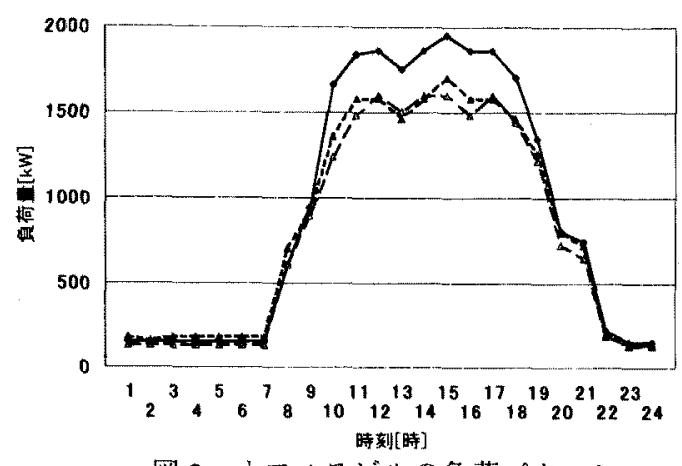

図 2 オフィスビルの黄荷パターン

Fig.2. Load Patterns in an Office Building.

表 1 保護装置の固定費

Table.1. Fixed Cost of Protector

\begin{tabular}{|c|c|c|}
\hline 機器名称 & 交流用 & 直流用 \\
\hline 配線用遮断器 & & \\
$20 \mathrm{~A}$ & 1,000 & 1,500 \\
$100 \mathrm{~A}$ & 30,000 & 50,000 \\
$400 \mathrm{~A}$ & 100,000 & 150,000 \\
低压遮断器 & & \\
$100 \mathrm{~A}$ & 100,000 & 150,000 \\
$200 \mathrm{~A}$ & 200,000 & 300,000 \\
$400 \mathrm{~A}$ & 300,000 & 450,000 \\
$1000 \mathrm{~A}$ & 600,000 & $1,000,000$ \\
$2000 \mathrm{~A}$ & $1,200,000$ & $1,800,000$ \\
保讙リレー & & \\
過電流リレー & 35,000 & 100,000 \\
不足電压リレー & 20,000 & 40,000 \\
\hline
\end{tabular}

単位：円

(3)評価結果 需要家が総負荷に対してどの程度の直流 負荷を持ってい北ば，直流配電を導入することにより効果 が得られるかを定量的に評価するため，需要家の持つ総負 荷に対する直流受電の比率 $(\mathrm{X})$ をパラメータとして, 現行 の交流のみの受電の場合 $(X=0.0)$ とのコスト比較を行った。 得ら机た結果を図 3 に示す。図 3(a)では,「DC 負荷追征 運転」と FC出力を $1,300[\mathrm{~kW}]$ に固定した「FC 定格運転」 の比較を示している。この結果から，定格運転のような FC 運転に自由度がない場合は，大幅なコス卜增となることが わかる。コスト増加の主な理由としては，FC から交流負 荷への融通電力が増之, 変換器の口ス分, 固定費などが増 加するためである。

図 3(b)では,「DC 負荷追徙運転」と「コスト最小化」 の比較を示している。この結果より，比率が $0-0.6$ の場 合，すなわち総負荷に対して直流負荷が小さいときには, 「コスト最小化」の方が年間総コストで $0.1 \sim 0.2 \%$ (10万 － 30 万円)削滅されることがわかる。このことは，「DC 負荷追従運転」では，変換器でのロスを最小にするという 目的があるため，上下限制約の範囲内で，FC が直流負荷 に完全に追良するように運転するのに対して，「コスト最

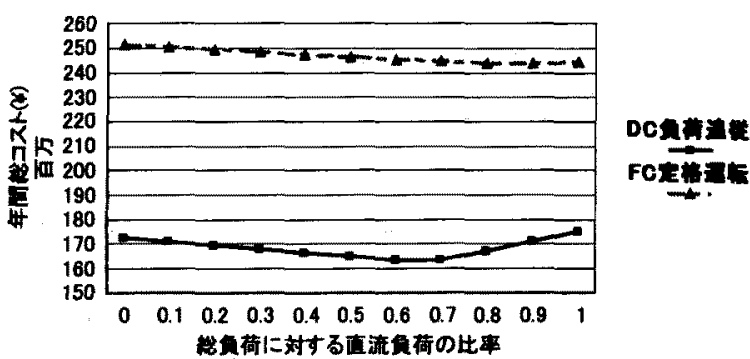

（a） DC 負荷追従型」と「FC 定格運転」の比較

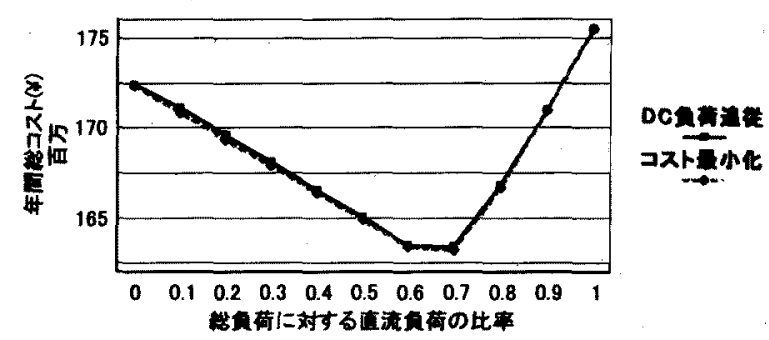

（b）「DC 負荷追従型」と「コスト最小化」の比較

図 3 直流負荷の比率と年間棇コスト

Fig.3. Ratio of DC Loads and Annual Total Cost.

小化」では，買電料金よりも安い燃料費の FC から交流負 荷へ供給する方が，変㨘器でのロス分を考虑してもコス卜 を削減できるためである。従って，FCの燃料費が高い場 合には，「コスト最小化」では FCの運用を控えめにする こととなり，「DC 負荷追従運転」とのコスト差はさらに 大きくなると考えられる。

また，各々の結果より，直流負荷を持つ需要家に対して 直流配電を導入することはコスト削減につながると言え る。特に図 3(b)より，総負荷に対して直流鱼荷を $95 \%$ ま で持つ需要家であれば，年間総コストは現交流配電方式 $(X=0.0)$ よりも低くなり、メリットが現れていることがわ 加る

\section{$<2 \cdot 3>$ 最適なFC容量および変換器容量の決定}

（1）最適な設備容量 前節では，FC 容量を $1,300[\mathrm{~kW}]$ と設定し，交流負荷と直流負荷の大きさをパラメータにと って年間総コスト（ランニングコスト十固定費）を算出し た。本節では逆に，交流負荷と直流負荷の大きさが，既に 与えられている場合に，QCC内に導入すべき最適な FC 容 量, コンバー夕容量を決定する手法について述べる。この 場合の問題は，以下のような制䄪付きコスト最小化問題と して定式化でき, 線形計画法(LP 法)を用いて解を求める ことができる。

\section{目的関数}

$$
\min Z=\sum_{x \in D_{x}} F_{x} \cdot C_{x}+\sum_{s=1}^{3} \sum_{t=1}^{24}\left(a P_{v}(s, t)+b P_{F c}(s, t)\right)
$$
ここに, $\mathrm{C}_{\mathrm{x}}$ : 機器容量, $\mathrm{F}_{x}$ : 固定費, $\mathrm{a}$ ：買電料金 $\mathrm{b}$ ：燃料費， $\mathrm{s}$ ：季節， $\mathrm{t}$ ：時間 


\section{制的条件}

・需給バランス制的

$\mathrm{P}_{r}+\mathrm{P}_{\mathrm{r}} / \eta \quad \mathrm{\eta P}-(1-\mathrm{x}) \mathrm{P} / \eta \quad=0 \quad\left(\mathrm{P}_{k r} \geqq \mathrm{xP}\right.$ の時 $)$

(3)

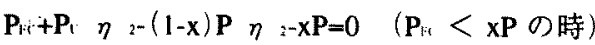

(4)

ここに, $\mathrm{x}$ ：直流負荷の比率， $\mathrm{P}$ ：総負荷,

$\eta, \eta:$ : 変換器効率

・ FCの制約

$\mathrm{P} r \mathrm{r} \leqq \mathrm{C}_{\mathrm{rr}} \quad$ : 上限制約

$\mathrm{P}_{\mathrm{rr}} \geqq \alpha \mathrm{C}_{\mathrm{H}} \quad$ : 下限制的

ここに， $\quad$ C $C_{1 \cdot}:$ 最低出力

・コンバータの制約

$$
\mathbf{P}_{\mathrm{r} r}-\mathrm{xP} \leqq \mathrm{C}_{\mathrm{row}} \quad\left(\mathbf{P}_{\mathrm{H}} \geqq \mathrm{xP}\right. \text { の時) }
$$$$
\left(\mathrm{xP}-\mathrm{P}_{\mathrm{r}}\right) / \eta_{2} \leqq \mathrm{C}_{\mathrm{rnis}} \quad\left(\mathbf{P}_{\mathrm{rr}}<\mathrm{xP}\right. \text { の時) }
$$

最終的に求めたい解は $\mathrm{Cr} ， \mathrm{C}_{\mathrm{r}} \mathrm{a}$ である。これらは，年 間総コストを最小にする，すなわち経済性の面から見て最 適な QCC 内設備容量として決定される。この結果より， 需要家が持つ交流・直流負荷が与えら机たとき, QCC 内 にどれだけの容量の FC および変換器を導入すれば経済的 であるかということを評価でき，QCC 内部の計画・設計 のための指針として用いることができる。

なお，上記の (3)(4)式は次のような意味を持っている。 すなわち，与えられた直流負荷と交流負荷に対する供給方 法は，図1からわかるように，以下の 2 通りが考えられる。

(1) FC が直流負荷以上の電力を発電し $\left(P_{w} \geqq x P\right)$, 余っ た分を交流負荷に供給する場合

(2) FC が直流負荷以下の電力を発電し $\left(\mathrm{P}_{\mathrm{r}} \leqq \mathrm{xP}\right)$, 足り ない分を系統電力で賄う場合

(1)の場合には，直流負荷にはすべて FC から供給し，交 流負荷には FC と系統電力の雨方によって供給することに なる。この場合，FC出力 $\left(\mathbf{P}_{\mathrm{r}}\right)$ が決まれば，FCの交流供 給分 $\left(\mathbf{P}_{\mathrm{F}}-\mathrm{xP}\right)$ も自ずと定まるため, 交流負荷の大きさから 従属的に系繶加の買い電電力の值が決定される。この関 係を表したものが(3)式である。一方，(2)の場合には，交 流負荷にはすべて系統電力から供給し, 直流負荷にはFC と系統電力によって供給することになる。この場合, 系梳 からの買い電電力 $\left(P_{1}\right)$ が決ま机ば, 系統電力の直流供給 $\left(\mathbf{P}_{\mathrm{r}}-(1-\mathrm{x}) \mathbf{P}\right)$ 分も自ずと定まるため, 直流電力の大きさか ら徉属的に FC 出力の值が決定される。この関係を表した ものが(4)式である。従って，いずれの場合も，(3)式(あ るいは(4)式)を満たす限りは, 直流負荷, 交流負荷それぞ れの需給バランスが満足される。

図 4 は, 需要家の持つ直流負荷の比率に対する最適な FC 容量, コンバー夕容量を示したものである。なお，デー夕 は前節の值を用いた。需要家の持つ直流負荷が多くなると， その直流負荷に対して電力を供給する FC の導入量が比例 して多くなることがわかる。この理由としては亲統からの 買電料金よりも FC の燃料費が安いことと，FC を導入す ることにより系統からの融通電力のためのコンバータの固 定費と変換器口ス分が低隇されることがあげられる。しか

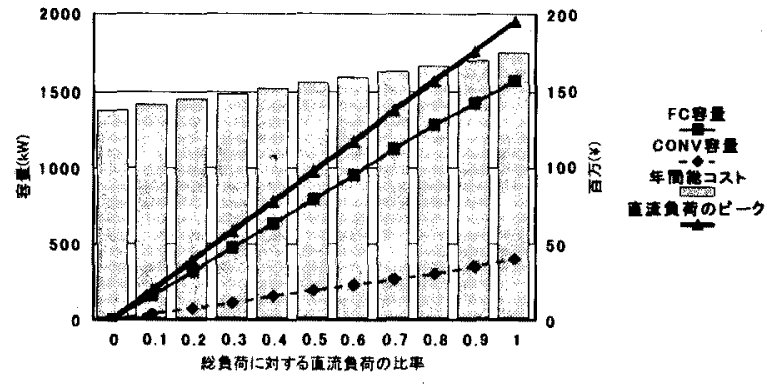

图 4 最適な設備容量

Fig.4. Optimal Capacities of every Facility.

し，FCの導入量は必ずしも直流負荷のピークと一致して いない。寸なわち，一部の直流負荷は系統からコンバー夕 を介して供給さ扎ている。こ机は，FC 抢よびコンバー夕 の固定費が高いため，ここで用いた買電料金 18.08 [ $/ \mathrm{kWh}$ ] と FCの燃料費 16.19[¥/kWh]の差では，すべてを FCで供 給するとコスト的に不利になるためである。また，FCお よびコンバータの固定費が高いということは，図4 加も わかるように需要家の持つ直流負荷が増えていくと, FC とコンバータの導入に伴い，年間総コストが高くなってい くことにつながる。したがって，FC の燃料費が安くなる があるいはFCとコンバータの固定費が安くなることが， QCC に直流配電が導入された場合に FC およびコンバータ が設置されることによるコスト削減を可能にする。

(2)FCの然料責をパラメータにとった評価（1）で考察 したことを確認するため，ここでは (2)一(8)式において然 料費をパラメー夕にとり，然料費がどの程度安くなれば $\mathrm{QCC}$ 内の FC およびコンバー夕導入による経済的なメリッ トが得られるかについて娭討した。結果を図 5 に示す。こ の結果より，燃料費が $11.59[\mathrm{z} / \mathrm{kWh}]$ までは図 4 でも示さ れた通り，現在の交流配電方式 $(X=0.0)$ の年間総コスト

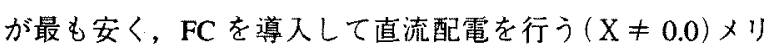
ットはないことになる。すなわち、いかなる需要家にも FC 導入のメリットはないことを示している。これに対して， FCの然料費が $11.59[¥ / \mathrm{kWh}] よ り も$ 安い場合には, FC 導入して部分的に直流配電を行うことで，現行の交流配電
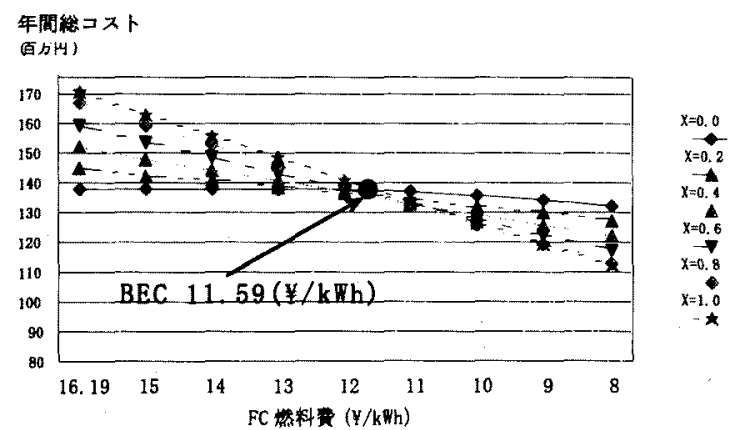

图 $5 \mathrm{FC}$ 燃料費をパラメータとした結果 Fig.5. Annual Total Cost versus Fuel Cost of FC 
方式よりも年間総コストが安くなることがわかる。すなわ ち, 直流で動作する負荷には，FC を導入して直流で供給 する方式に切り替えることで，メリットが現れることにな る。従って，この点を境にして, FC を導入した直流配電 のメリットが現れることとなり，直流配電を可能とする FC 燃料費のブレークイーブンポイント(BEP) と言える。

将来的に FRIENDS が導入される際に, 経済的な効果を 引き出すため FC の燃料費を BEP まで下げるには，FCの 燃料となる LNG 単価が安くなるか，FCの効率が增加する ことが必要であり，今後の研究開発に期待したい。

(3) QCC内設備の固定費をパラメータにとった評価こ こでは(2)－(8)式において FC とコンバータの固定費をパ ラメータにとり，固定費がどの程度まで安くなれば QCC 内の FC およびコンバー夕導入による経済的なメリットが 得られるかについて検討した。コンバータの固定費を初期 值 150,000[¥/kVA] 設定し, FC の固定費をパラメータに とった結果を图 6 に示す。この結果より，FCの固定費が 24,000 [ $¥ / \mathrm{kW}$ ] (現状の 24\%) までは, 前述のごとく, 現在 の交流配電方式 $(X=0.0)$ の年間総コストが最も安く, FC

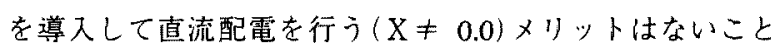
になる。一方, 固定費が $24,000[\mathrm{Z} / \mathrm{kW}$ 」 よりも安くなると, FC を導入した直流配電のメリットが現れることとなり，(2) と同様に, この值は直流配電を可能とする FC 固定費の BEP と言える。

次に、コンバータの固定費をパラメータにとり試算した

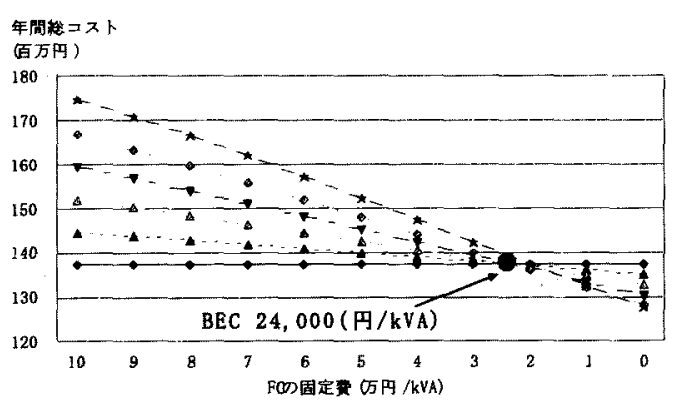

$x=0.0$
$x=0.2$
$x=0.4$ $x=0.4$ $x=0.6$ $x=0.8$
$i$
$x=1.0$

图 6 FC 固定費をパラメータとした結果

Fig.6. Annual Total Cost versus Fixed Cost of FC.

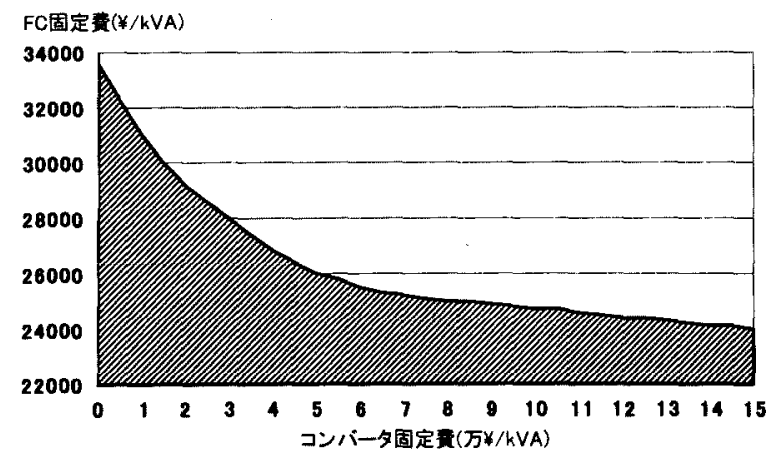

图7 QCC 内設備の固定費をパラメータとした結果

Fig.7. Merits versus Fixed Costs of $\mathrm{FC}$ and Convertor.
結果を图 7 に示す。ここで，図中の斜線部分まで固定費を 抑えることができ礼ば，交流配電システムに比べ経済的な メリットが得られることを示している。また，同図より FC 固定費を 34,000[丵/kVA]から 24,000[¥/kVA]まで下げるこ とは，コンバー夕固定費の上昇を約 15 万円まで許容する ことを可能とする。このことから，年間総コストが高くな る原因は FC の固定費が高いことに重みがあることがわか り，直流配電の FC に依存する部分が大きいことを示して いる。

将来的に FRIENDS が導入される際に経消的な効果を引 き出すためには，直流配電に影響の強い FC の固定費を BEP まで下げるか，FCの年経費率を下げるために耐用年 数を增すような研究開発が必要になるであろう。

\section{3. 品質別供給を考慮した直流配電導入の効果}

く3・1>解析モデルおよび定式化 品質別供給を行うモ デルとして，前章まで単一品質として扱ってきた交流・直 流負荷をそれぞれ品質別に分けて, 多品質電力供給を考慮 した最適な QCC 内の設備容量の決定手法について検討す る。なお，ここでの「品質」としては，特に供給信頼度を 考えている。従って，何らかの理由で柔統からの供給が停 止しても $\left(\mathrm{Pr}_{\mathrm{r}}=0\right), \mathrm{QCC}$ は少なくとも高品質負荷に電力供 給できなければならず，そのための分散電源を一定程度保 有していることが必要となる。また，QCC 内に導入され る分散電源としては，FC とマイクロガスタービン (Micro Gus Turbine：MGT)の 2 種類を考慮する。このモデルに対 して，交流負荷と直流負荷の大きさがそれぞれ与えられて いる場合に，QCC 内に導入すべき最適な分散電源容量

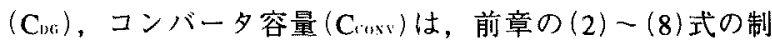
約付きコスト最小化問題に，さらに以下の上うな分散電源 の制約 (9)式と，コンバータの制約 (10)式を加えて計算す ることができる。

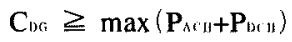

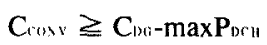

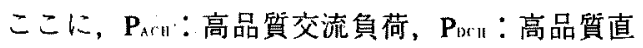

$$
\begin{aligned}
& \text { 流負荷 }
\end{aligned}
$$

なお，(9)，（10)式は高品質負荷への電力供給を行うた めの制約でありこここでは事故時に㧍ける他 QCC からの 電力融通は考慮していない。すなわち，分散電源の容量は 高品質負荷以上必要となる。ところで, MGT の場合は, 定格回転数が 100,000rpm 前後と非常に高速であるため， 系統に連系寸る際には通常直流に変換してから，インバー 夕で再び商用周波数に変換する必要がある。従って, 直流 配電を行う場合には，その直流部を直接利用することにな $z^{|x|}$ 。

データとしては, FC システムについてはく2.2>節の值を 用い, MGT システムについては燃料単価 13.88[¥/kWh], 固定費 70,000[¥/kVA], 年経費率 0.211 の MGT と, 入出 力効率 $93 \%(\mathrm{AC} \rightarrow \mathrm{DC})$, 固定費 $60,000[¥ / \mathrm{kVA}]$ ，年経費率 
0.13 [酎用年数 15 年]のコンバー夕を保有するものとする。 ここで, MGTについては系統連系用のインバー夕を最初 から含んだコストデータを与えている。そのため, 交流負 荷へ電力供給するための変換器索新たに設置する必要がな く，(7)，(10)式の制約は不要となる。

$<3.2>$ 試算結果比較的高品質負荷の多い負荷地域と して，前節のオフィスビルの負荷パターンを用いて試算を 行った。なお，高品質負荷と標染品質負荷の割合を $7: 3$ と仮定した。得られた結果を図 8 に示す。この図は分散電 源として FC、MGTをそ扎ぞれ考慮した場合に村して，需 要家の持つ総負荷に対する直流負荷の比率をパラメータと して, 最適な分散電源容量, 変換器容量を示したものであ る。FC, MGT のいずれの場合も，直流鿓荷の比率が 0.7 一 0.8 で年間総コストが最小になっており，分散電源を非 常㭙の高品質電力供給源として導入することにより，交流 のみの品質別供給(すなわち総負荷に対する直流負荷の比 率が 0.0 の点よりもメリットがあることがわかる。比率 が 0.7 - 0.8 以下では，分散電源が交流・直流それぞれの 高品質負荷を補償する分だ導入されており，直流負荷が 增えていくと，変換器による損失電力量が隇少し，年間縃 コストも滅少する。一方, 比率が $0.7 \sim 0.8$ 以上では，分 散電源が直流・交流の高品質負荷のみならず標準品質の直 流負荷をも供給した方が経済的なことから，導入量は直流 負荷に栟って增加する。たたし，分散電源の導入量は必ず しも直流負荷のピークと一致していない。これは，一部系 統から変換器を通して直流負荷に供給した方がコス卜的に 有利になる場合があるため，分散電源の導入量が抑えられ るからである。それにより，コンバー夕容量は増加するこ とになる。また，FC，MGT 両方を比較子ると，分散電源 が MGT の場合，FCよりも導入コストが安いため，大き くコスト削减されていることがわかりる。

図 9 は，同様にオフィスビルの頁荷パターンを用いて， QCC 内に分散電源がない場合の年間総コストと，QCC 内 の分散電源を FC，MGTにした場合の品質別供給の有無に よる年間総コストの比較を示したものである。この結果よ り，QCC内の分散電源として FC を導入した場合，現状の コストデータのままで直流配電を行うと，現行の交流配電 システムと比べてコストメリットが得られないことがわか

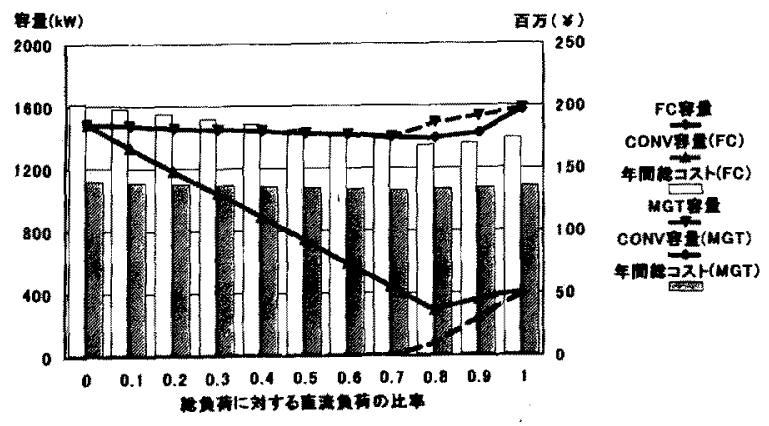

因 8. 設備容量と年間総コス卜

Fig.8. Capacities of Facilities and Annual Total Cost.

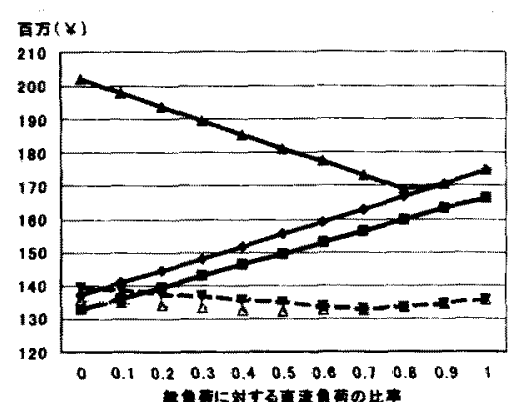

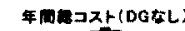
4.

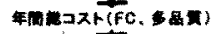

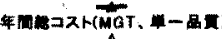

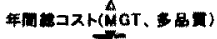

図 9. 年間緦コストの比較(オフィスビル)

Fig.9. Annual Total Costs (Office Building).

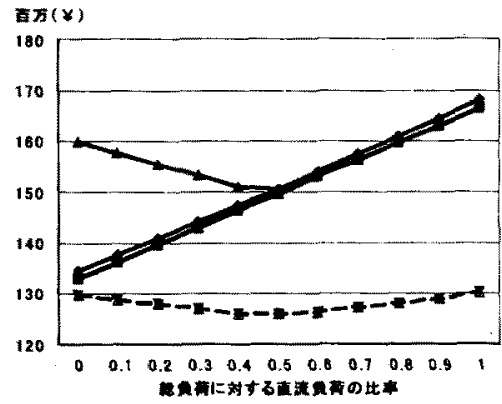

年血異コスト(DGな

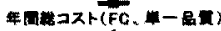

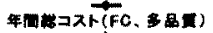

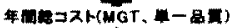

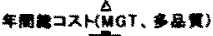

図 10.年間総コストの比較(住宅地域)

Fig.10. Annual Total Costs (Residential Region).

る。また，品誓別供給を行う場合には，直流配電導入によ ってコスト削隇がなされているが,単一品質供給に比べて， コストが大幅に增加してしまう。しかし，同様に分散電源とし てMGT 考慮した場合は，直流配電を考慮することで年 間総コストは削減され，品質别供給を行う場合にもコス卜 が低く抑えられることから FC に比べて導入されやすいこ とがわかる。

一方，標準品質真荷の方が多い住宅地域の負荷パターン 行を用いて高品質負荷：標準品質負荷の割合を $3: 7$ と仮 定して，同様に試算した。得られた結果を图10に示す。 この結果より，品質別供給を考慮した場合には，オフィス ビルモデルほどコストメリットが現れていないが，同様に FC およびMGT の両ケースにおいて，ある直流筫荷の比

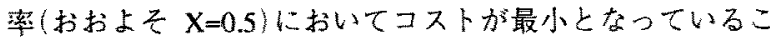
とがわかる。また，住宅地域では高品質負荷が少ないため， 直流負荷が多くなると分散電源の導入により交流配電シス テムの品質別供給よりも年間総コストが高くなり，導入さ れにくくなる部分が出てくる。

以上のことから，現在のシステムとのコスト比較により QCC 内に導入すべき最適な分散電源容量を決定すること が重要であることがわかる。

4.まとめ

本論文では，将来的に配電システムに導入されるであろ 
う FRIENDS の一機能としての直流配電について, 需要家 側負荷のパラメータ解析による検討を行った。また, 交流 負荷と直流負荷の大きさが既に与えられている場合の最適 な分散電源容量や変換器容量を決定する手法を開発し, モ デル系統による試算を行った。これらの結果から，直流配 電を導入することにより，年間の総コストを抑えることが 可能であることが確認でき, 需要家の持つ直流負荷の大き さに対して導入すべき QCC 内設備の各容量も決定できる ことが確かめられた。また, 直流配電の導入にあたり, FC およびコンバータの価格を将来的にどれだけ抑えることが できれば, 交流配電システムに比べて, 経済的なメリット が得られるかということを定量的に評価した。さらに，需 要家の持つ交流・直流負荷をそれぞれ品質別に分けて, 多 品質電力供給を考慮した直流配電についても, 需要家負荷 のパラメータ解析により検討を行った。ここで, QCC 内 に導入される分散電源としては, FC とマイクロガスター ビンの 2 種類を考慮し比較唡討した。分散電源として導入 コストの安いマイクロガスタービンを導入した上で, 直流 配電を導入することにより，年間の総コストを抑えること が可能であることが確認された。

今後は, 品質別供給まで考える際に, 直流配電を導入す ることで減少が期待される停電コストを取り込むことで,

トータル的に見た社会コストを算定し, 評価することが課 題となるであろう。また，これからますます需要家側に分 散電源が導入された場合, 需要家側の分散電源からの逆潮 流などが存在することを念頭にいれ，システムを構築して いく必要があろう。

最後に, 本研究は文部省科学研究費基盤研究 (B)(一般 研究) (展開研究), 同国際学術研究 (共同研究) の研究助成 を受けていることを付記する。

(平成 12 年 2 月 28 日受付, 平成 12 年 6 月 8 日再受付)

\section{文献}

[1] 岡村:「直流集配電システムの予備検討」, 電力中央研究 所報告, T92058 (1993)

[2]「特集：分散型電源 Q\&A」, OHM '93/11，pp.25-63

[3] 奈良, 長谷川：「新しい柔軟な電気エネルギー流通システ 厶」, 電学論 B, vol.117, No.1, pp.47-53(1997)

[4] 三島, 北, 長谷川：「高柔軟・高信頼電気エネルギー流通 システム（FRIENDS）に㧍ける電力改質センターの内部構 成の一提案」, 電学論 B, Vol.118, No.11, pp.1292-1301 (1998)

[5] T. Ishikawa, B. Kamimura : "Possibility of DC Power Supply in Commercial Buildings", proc. of Japan-US Seminar on Intelligent Distributed Autonomous Power Systems (IDAPS) (1998)

[6]「電気用品等の直流電力供給による使用の可能性調查」, NEDO-P-8422 (1985)

[7]尾島研究室：「建築の光熱水原単位〔東京版〕, 早稲田大 学出版部 (1995)
[8]「特設記事：マイクロガスタービン」, OHM '99/4, pp.55-61

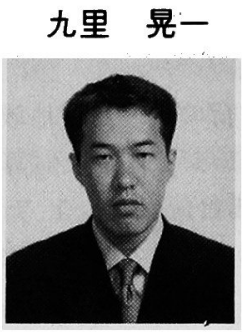

\section{北裕幸}

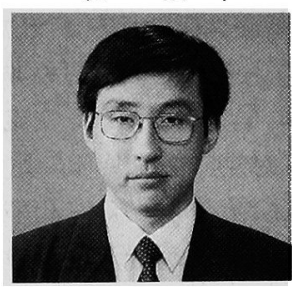

(正員) 1974 年 5 月 10 日生。 2000 年 3 月北海道大学大学院工学研究科 ステム情報工学専攻修士課程修了。 同年 4 月中部電力 (株) 入社。現在, 緑営業所に勤務。在学中, 主として FRIENDS の経済性評価に関する研 究に従事。 文賞受賞。主として, 電力系統の計画・運用・制御に関す る研究に従事。日本 OR 学会, 電気設備学会会員。

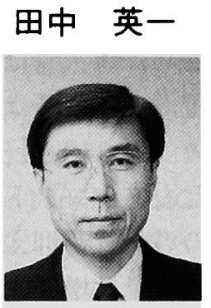

(正員) 1952 年 8 月 12 日生。 77 年 3 月北海道大学大学院工学研究科電気 工学専攻修士課程修了。同年 4 月同 大学工学部電気工学科助手, 95 年 4 月改組により, 同大学大学院工学 研究科システム情報工学専攻に配置 換えとなり，現在に至る。主として， 電力系統の解析・制御に関する研究に従事。日本 OR 学会, 電気設備学会, 計測自動制御学会会員。

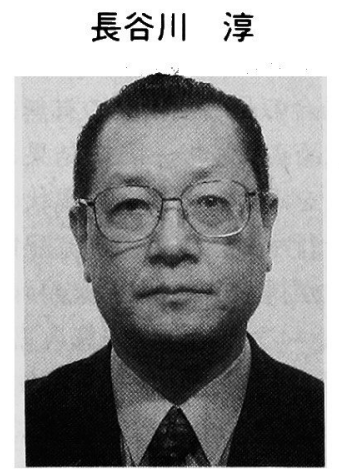

(正員) 1943 年 12 月 13 日生。71 年 3 月北海道大学大学院工学 研究科電気工学専攻博士課程 修了。同年 4 月同大学工学部 電気工学科講師, 同助教授を 経て, 85 年 4 月同教授。95 年 4 月改組により, 同大学大学 院工学研究科システム情報工 学専攻に配置換えとなり, 現 在に至る。工学博士。平成 9 年度論文賞受賞。平成 6 年

度 $\mathrm{B}$ 部門長, 同 9 年度副会長 (調査担当)。主として, 電力 系統の計画・運用・解析・制御および電気エネルギー工学 全般に関する研究に従事。IEEE，照明学会，エネルギー - 資源学会, 低温工学協会, 日本 OR 学会, 電気設備学会, 等, 会員。 
電力・エネルギー部門大会座長のコメントと回答

一A 25 新型電力供給システム—

\section{質 疑}

\section{座長 伊庭 健二}

\section{同セッションでの対象論文への質疑応答}

（1）直流配電については供給電圧は固定するのか。負 荷の機器によって定格電圧は異なるが…

（2）FC を考える場合，熱供給によるコスト回収は考 慮しているの加?

（3）オフィスビルと一般住宅モデルでは，年間総コス 卜比較の結果に差があるが，モデルの差異として何のファ クタが大きいか?

\section{応 答}

九里 晃一・北裕幸

田中 英一・長谷川 淳（北海道大）

同セッションでの質疑応答」に対する追加説明

(1) 本論文のモデル化においては，ビル内部の実際の
負荷機器までは考慮して抢らず，ビルが QCC から受電す る際の直流電力をパラメータとして与え，QCCの経済性 評価を行っている。したがって，ここでは実際に使用する 際の種々の電圧レベルについては考慮していない。

（2）本論文では，分散電源による「直流配電」の効果 を評価することを目的として抢り，分散電源の「熱供給」 の効果についてはあえて考慮していない。なお，熱供給に よるコスト回収を考えれば，分散電源に有利に㗢き，導入 の可能性活に大きくなるものと予想される。

（3）分散電源は高品質負荷へ電力供給するための設備 としてモデル化されている。したがって，多品質電力供給 が一般的となっているような状況下においては，現状の交 流受電方式（直流比率＝0.0）であっても，高品質負荷に 供給するための分散電源が導入されていることになる。こ こで, 需要家が直流受電をも行う場合には, 多品質電力供 給のために導入されている分散電源を，直流供給にも用い ることができるため, 直流受電の比率が増加するにつれ， 年間総コストは滅少していくことになる。特に,オフィス ビルの場合，総負荷に対する高品䝷電力の割合が一般住宅 に比べ大さいため，分散電源の導入割合もより大きいと考 えられる。したがって，オフィスビルで，直流受電の比 率がより大きなケースで, 導入メりットが最大（年間コス トが最小となる傾向があるといえる。 